\title{
Polymorphisms of genes coding for insulin-like growth factor I and its major binding proteins, circulating levels of IGF-I and IGFBP-3 and breast cancer risk: results from the EPIC study
}

\author{
F Canzian', JD McKay', RJ Cleveland', L Dossus', C Biessy', S Rinaldi', S Landi', C Boillot', S Monnier', \\ V Chajès ${ }^{2}$, F Clavel-Chapelon ${ }^{2}$, B Téhard ${ }^{2}$, J Chang-Claude ${ }^{3}$, J Linseisen ${ }^{3}$, PH Lahmann $^{4}$, T Pischon ${ }^{4}$, \\ D Trichopoulos ${ }^{5}$, A Trichopoulou ${ }^{5}$, D Zilis ${ }^{5}$, D Palli, R Tumino $^{7}$, P Vineis ${ }^{8,9}$, F Berrino ${ }^{10}$, \\ HB Bueno-de-Mesquita'", CH van Gils'2, PHM Peeters' ${ }^{12}$, G Pera ${ }^{13}$, E Ardanaz ${ }^{14}$, M-D Chirlaque ${ }^{15}$, \\ JR Quirós ${ }^{16}$, N Larrañaga ${ }^{17}$, C Martínez-García ${ }^{18}$, NE Allen ${ }^{19}$, TJ Key'19, SA Bingham ${ }^{20}$, K-T Khaw ${ }^{21}$, \\ N Slimani', T Norat', E Riboli' and R Kaaks*,'
}

'International Agency for Research on Cancer, Lyon, France; ${ }^{2}$ Institut Gustave Roussy, Villejuif, France; ${ }^{3}$ German Cancer Research Centre, Heidelberg, Germany; ${ }^{4}$ German Institute of Human Nutrition, Potsdam, Germany; ${ }^{5}$ University of Athens Medical School, Athens, Greece; ${ }^{6}$ CSPO-Scientific Institute of Tuscany, Florence, Italy; ${ }^{7}$ Cancer Registry, Azienda Ospedaliera 'Civile MP Arezzo', Ragusa, Italy; 8 Imperial College, London, UK; ' University of Torino, Turin, Italy; ${ }^{10}$ National Cancer Institute, Milan, Italy; "National Institute of Public Health and the Environment, Bilthoven, The Netherlands; ${ }^{2}$ Julius Center for Health Sciences and Primary Care, University Medical Center, Utrecht, The Netherlands; ${ }^{13}$ Catalan Institute of Oncology, Barcelona, Spain; ${ }^{14}$ Instituto de Salud Pública, SNS-O, Pamplona, Spain; ${ }^{15}$ Epidemiology Department, Murcia Health Council, Spain; ${ }^{16}$ Public Health Directorate, Consejería de Sanidad y Senvicios Sociales de Asturias, Oviedo, Spain; ${ }^{17}$ Public Health Division of Gipuzkoa, Health Department of the Basque Country, San Sebastián, Spain;

${ }^{18} \mathrm{~S}$ chool of Public Health of Andalucia, Granada, Spain; ${ }^{19}$ Cancer Research UK, Epidemiology Unit, University of Oxford, Oxford, UK;

${ }^{20}$ MRC Dunn Human Nutrition Unit, Welcome Trust/MRC Building, Cambridge, UK; ${ }^{2}$ Clinical Gerontology Unit, Addenbrooke's Hospital, Cambridge, UK

Insulin-like growth factor I (IGF-I) stimulates cell proliferation and can enhance the development of tumours in different organs. Epidemiological studies have shown that an elevated level of circulating IGF-I is associated with increased risk of breast cancer, as well as of other cancers. Most of circulating IGF-I is bound to an acid-labile subunit and to one of six insulin-like growth factor binding proteins (IGFBPs), among which the most important are IGFBP-3 and IGFBP-I. Polymorphisms of the IGFI gene and of genes encoding for the major IGF-I carriers may predict circulating levels of IGF-I and have an impact on cancer risk. We tested this hypothesis with a case-control study of 807 breast cancer patients and 1588 matched control subjects, nested within the European Prospective Investigation into Cancer and Nutrition. We genotyped 23 common single nucleotide polymorphisms in IGFI, IGFBPI, IGFBP3 and IGFALS, and measured serum levels of IGF-I and IGFBP-3 in samples of cases and controls. We found a weak but significant association of polymorphisms at the $5^{\prime}$ end of the IGFI gene with breast cancer risk, particularly among women younger than 55 years, and a strong association of polymorphisms located in the $5^{\prime}$ end of IGFBP3 with circulating levels of IGFBP-3, which confirms previous findings. Common genetic variation in these candidate genes does not play a major role in altering breast cancer risk in Caucasians.

British Journal of Cancer (2006) 94, 299-307. doi: I 0.1038/sj.bjc.6602936 www.bjcancer.com

Published online 10 January 2006

(C) 2006 Cancer Research UK

Keywords: IGF-I; IGFBP-3; IGFBP-I; IGFALS; single nucleotide polymorphisms; breast cancer

Insulin-like growth factor-I (IGF-I) is a peptide growth factor that exerts mitogenic and metabolic activities that are regulators of growth, survival and cell differentiation in a number of cell and tissue types. A number of epidemiologic studies have shown a direct association between circulating IGF-I levels and breast

*Correspondence: Dr R Kaaks, Hormones and Cancer Team, International Agency for Research on Cancer, 150, cours Albert-Thomas, F-69372 Lyon, France; E-mail: kaaks@iarc.fr

Received 22 April 2005; revised 17 November 2005; accepted 21 November 2005; published online 10 January 2006 cancer risk, especially in young women (Peyrat et al, 1993; Bruning et al, 1995; Bohlke et al, 1998; Hankinson et al, 1998; Toniolo et al, 2000; Muti et al, 2002; Yu et al, 2002). Elevated circulating IGF-I also has been found to be a potential cancer risk factor for cancers of other organs, such as the prostate (Mantzoros et al, 1997; Chan et al, 1998; Wolk et al, 1998; Stattin et al, 2000) and the colorectum (Ma et al, 1999; Giovannucci et al, 2000; Kaaks et al, 2000; Palmqvist et al, 2002).

Most of the circulating IGF-I originates from the liver. In the circulation, it is either free or bound to one of six high-affinity binding proteins, which regulate IGF-I activity. About $90 \%$ of the circulating IGF-I is bound to insulin-like binding protein-3 
(IGFBP-3), which forms a ternary complex with an acid-labile subunit (ALS). The smaller complexes are able to pass the vascular endothelial barrier and therefore may be important modulators of IGF-I activity at the cellular level (Jones et al, 1993; Rajaram et al, 1997). There is physiologic evidence of a role for IGFBPs to work either in an IGF-I-dependent, such as increasing the half-life of IGF-I and modulating access to the IGF-I receptor, or IGF-Iindependent fashion by mediating their effects directly on target cells, where they generally have a proapoptotic role (Jones et al, 1993; Perks et al, 1999; Gleeson et al, 2001; Mohan and Baylink, 2002).

While nutrition is an important determinant of circulating IGF-I levels (Thissen et al, 1994; Kaaks and Lukanova, 2001), heritability studies have shown that up to $40-60 \%$ of the variation in circulating IGF-I levels is determined by genetic factors (Harrela et al, 1996; Verhaeghe et al, 1996; Hong et al, 1997; Hall et al, 1999). So far, however, only few studies have been conducted to identify specific gene variants that influence circulating IGF-I levels, even though such research is currently intensifying (Hasegawa et al, 2000; Lopez-Bermejo et al, 2000; Jernstrom et al, 2001a; Vaessen et al, 2001).

For the present study, we focused on 23 common single nucleotide polymorphisms (SNPs) that we estimated would have the highest chance of having an impact on either the expression or function of IGF-I and of molecules (IGFBP-1, IGFBP-3 and IGFALS) involved in IGF-I transport. We conducted a casecontrol study of 807 breast cancer patients and 1588 matched control subjects, nested within the cohorts of the European Prospective Investigation into Cancer and Nutrition (EPIC) (Riboli et al, 2002; Bingham and Riboli, 2004), and examined relationships of these polymorphisms with circulating IGF-I and IGFBP-3 levels, as well as breast cancer risk.

\section{MATERIAL AND METHODS}

\section{The EPIC study}

The EPIC cohort consists of about 370000 women and 150000 men, aged 35-69 years, recruited between 1992 and 1998 in 23 research centres in 10 Western European countries. Although detailed information on ethnicity of EPIC subjects is not available, in practice, recruitment has not been conducted in large cosmopolitan urban areas; therefore, owing to the current ethnic composition of the regions involved in the study, we estimate that the vast majority $(>97 \%)$ of subjects recruited in the EPIC cohort are of Caucasian origin. All EPIC study subjects provided anthropometric measurements (height, weight, waist and hip circumferences) and extensive, standardised questionnaire information about medical history, diet, physical activity, smoking and other lifestyle factors. Women also answered questions about menstrual and reproductive history, hysterectomy, ovariectomy and use of exogenous hormones for contraception or treatment of menopausal symptoms. In addition, about 240000 women and 140000 men provided a blood sample.

Cases of cancer occurring after recruitment into the cohort are identified through local and national cancer registries in seven of the 10 countries, and in France, Germany and Greece by a combination of contacts with national health insurances and/or active follow-up through the study subjects or their next of kin. Follow-up on vital status, to monitor the population remaining at risk for cancer, is achieved through record linkage with mortality registries. In all EPIC study centres, cancer diagnosis is confirmed through comprehensive review of pathology reports, and checks for completeness of follow-up are made periodically. A fully detailed description of the EPIC study has been published elsewhere (Riboli et al, 2002; Bingham and Riboli, 2004).

\section{Selection of case and control subjects}

Cases and controls from the present study were from 16 of the 23 EPIC recruitment centres, in seven of the 10 countries participating in EPIC (UK, Germany, The Netherlands, France, Spain, Italy and Greece), and were part of a larger nested case-control study on serum hormones and breast cancer risk, reported in detail elsewhere (Kaaks et al, 2005a,b; Rinaldi et al, manuscript submitted).

Case subjects were selected among women who developed breast cancer after their recruitment into the EPIC study, and before the end of the study period, for each study centre defined by the latest end-date of follow-up. Women who used any hormone replacement therapy at the time of blood donation, or any exogenous hormones for contraception or medical purposes, and who had previous diagnosis of cancer (except non-melanoma skin cancer) were excluded from the study, because each of these various factors could have altered circulating hormone levels.

For each case subject with breast cancer, two control subjects were chosen at random from among cohort members alive and free of cancer (except non-melanoma skin cancer) at the time of diagnosis of the index case. Control subjects were matched to the cases by study centre where the subjects were enrolled in the cohort, as well as by menopausal status (premenopausal, postmenopausal, perimenopausal/undefined), age ( \pm 6 months) at enrolment, follow-up time, fasting status, time of the day of blood donation and phase of the menstrual cycle for premenopausal women (assessed according to criteria defined by Kaaks et al).

Approval for the study was given by the relevant Ethical Committees, both at the IARC and in each of the EPIC recruitment centres.

\section{Identification and selection of SNPs}

We collected data on polymorphisms from publicly available databases, such as dbSNP (http://www.ncbi.nlm.nih.gov/SNP/), SNPper (http://snpper.chip.org/) and Frequency Finder (http:// bluegenes.bsd.uchicago.edu/frequencyfinder/). We complemented database searches with literature review and, for IGFBP1 and $I G F B P 3$, with analysis of 95 subjects from the EPIC population by denaturing high-performance liquid chromatography (DHPLC; Xiao and Oefner, 2001).

To be included in the study, polymorphisms had to be located in exons (including untranslated regions), exon-intron junctions or promoter regions of a gene of interest, or otherwise should be within intronic regions that showed greater than $80 \%$ homology between human and mouse (as reported by the UCSC Genome Browser, http://genome.ucsc.edu/), and thus were likely to harbour regulatory sequences. We included only polymorphisms whose existence in Caucasians is documented, either according to literature data or to our own experimental analysis by DHPLC. All new SNPs identified in our laboratory by DHPLC searches have been deposited in dbSNP (http://www.ncbi.nlm.nih.gov/SNP). Among all polymorphisms thus identified, we retained only those with a minor allele frequency $\geqslant 5 \%$ in Caucasians or those that result in an amino-acid change and had a minor allele frequency $\geqslant 1 \%$. Finally, we particularly favoured the inclusion of all polymorphisms that were previously reported in the literature to be associated with cancer risk and/or levels of circulating hormones. In total, this strategy led to a list of 26 SNPs for genotyping.

\section{Genotyping}

Buffy coat samples for the study subjects were retrieved from the EPIC biorepository and DNAs were extracted on an Autopure instrument (Gentra Systems, Minneapolis, MN, USA) with Puregene chemistry (Gentra Systems, Minneapolis, MN, USA). 
Genotyping was performed by the $5^{\prime}$ nuclease assay (TaqMan). The order of DNAs from cases and controls was randomised on PCR plates in order to assure that an equal proportion of cases and controls could be analysed simultaneously. TaqMan probes were synthesised by either Applied Biosystems, Foster City, CA, USA (with MGB chemistry) or Proligo, Paris, France (with or without LNA chemistry). Sequences of primers and probes are reported in Supplementary Table 1. For one SNP, a genotyping assay could not be designed and for two more SNPs, TaqMan assays were generated but provided poor genotyping results. This left 23 polymorphisms that were genotyped on the DNAs of cases and controls (Table 1). The reaction mix included $10 \mathrm{ng}$ genomic DNA, $5 \mathrm{pmol}$ of each primer, 1 pmol of each probe and $2.5 \mu \mathrm{l}$ of $2 \times$ master mix (Applied Biosystems) in a final volume of $5 \mu \mathrm{l}$. The thermocycling included 50 cycles with $30 \mathrm{~s}$ at $95^{\circ} \mathrm{C}$ followed by $60 \mathrm{~s}$ at $60^{\circ} \mathrm{C}$. PCR plates were read on an ABI PRISM 7900HT instrument (Applied Biosystems). Laboratory personnel was kept blinded to case-control status throughout the study. Genotyping call rates ranged between 95.27 and $99.44 \%$. The distributions of genotypes of all polymorphisms were in agreement with the Hardy-Weinberg equilibrium (calculated in the control group). Repeated quality control genotypes ( $8 \%$ of the total) showed greater than $99 \%$ concordance for all assays.

\section{Hormone measurements}

Measurements of IGF-I and IGFBP-3 were performed in the laboratory of the Hormones and Cancer, at IARC, using enzymelinked immunosorbent assays from Diagnostic System Laboratories (DSL, Webster, TX, USA). The IGF-I assays included an acid-ethanol precipitation step to eliminate IGF-I binding proteins, to avoid their interference with the IGF-I measurement. Measurements were performed on never thawed serum sample

Table I Polymorphisms used in the present study

\begin{tabular}{|c|c|c|c|}
\hline Polymorphism $^{a}$ & Alleles (major $>$ minor) & Position in gene & Codon \\
\hline \multicolumn{4}{|l|}{ IGFI } \\
\hline rs35765 & $C>A$ & Promoter region & \\
\hline rs35767 & $C>T$ & Promoter region & \\
\hline rs2162679 & $A>G$ & Intron I & \\
\hline rs6220 & $T>C$ & Exon $4 ; 3^{\prime}$ UTR & \\
\hline rs6214 & $C>T$ & Exon 4; $3^{\prime}$ UTR & \\
\hline \multicolumn{4}{|l|}{$|G F B P|$} \\
\hline rs|99505। & $G>A$ & Promoter region & \\
\hline rs 1065780 & $G>A$ & Promoter region & \\
\hline rs9658194 & $C>A$ & Intron I & \\
\hline rs3828998 & $T>C$ & Intron I & \\
\hline rs3793344 & $A>G$ & Intron I & \\
\hline rs49885I5 & $C>T$ & Exon 4 & Cys230Cys \\
\hline rs 4619 & $A>G$ & Exon 4 & Met253lle \\
\hline \multicolumn{4}{|l|}{ IGFBP3 } \\
\hline rs213257| & $G>A$ & Promoter region & \\
\hline rs2132572 & $G>A$ & Promoter region & \\
\hline rs 2854744 & $C>A$ & Promoter region & \\
\hline rs247I55I & $G>C$ & Intron I & \\
\hline P0453 & $C>T$ & Exon 4 & Thr277lle \\
\hline rs2453839 & $A>G$ & Exon4; 3' UTR & \\
\hline P0448 & $\mathrm{T}>\mathrm{C}$ & Exon4; 3' UTR & \\
\hline rs6670 & $A>T$ & Exon4; 3' UTR & \\
\hline \multicolumn{4}{|l|}{ IGFALS } \\
\hline rs375। 893 & $\mathrm{~T}>\mathrm{C}$ & Exon 2 & Asp70Asp \\
\hline rs 17559 & $C>T$ & Exon 2 & Tyr462Tyr \\
\hline rs2230053 & $G>A$ & Exon 2 & Thr522Thr \\
\hline
\end{tabular}

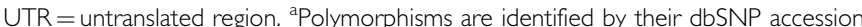
number. ${ }^{b}$ Internal references are used for polymorphisms not present in dbSNP. aliquots. The mean intra- and inter-batch coefficients of variation were 6.2 and $16.2 \%$ respectively for IGF-I, and 7.2 and $9.7 \%$ respectively for IGFBP-3.

\section{Statistical analysis}

Individual haplotype frequencies (i.e. estimated numbers of copies of haplotypes) were reconstructed using the program 'tagSNPs' (http://www-rcf.usc.edu/ stram/tagSNPs.html; Stram et al, 2003a,b). This program calculates, for each individual, the expected numbers of copies ('dosages') of each of the haplotypes compatible with the individuals' SNP genotypes. This method takes into account uncertainties in the haplotype reconstruction for individuals who are heterozygous for two or more of the SNPs within a given gene. Haplotype dosages are estimated from the individuals' SNP genotype data and from overall haplotype frequency estimates for the full study population (cases and controls combined) estimated by a maximum likelihood method. For each haplotype, the dosage values range from 0 to 2.0 (alleles), and for each individual these dosage values add up to a total value of 2.0 across all possible haplotypes.

All association analyses, at the level of individual SNPs or gene loci, were performed under different assumed modes of inheritance of effect - dominant, recessive or codominant - associated with alleles. In the 'dominant' model, circulating peptide levels or disease risks were compared between subjects carrying at least one copy of the rare allele and those who had none; in the 'recessive' model, the comparison was between those who were homozygous for the rare allele and all others; in the 'codominant' model, individuals' peptide levels or the logarithm of disease risk were linearly related to the number of copies of an allele $(0,1$ or 2 for SNP alleles, or dosages for the haplotype) carried by the individuals. For rare alleles, with a frequency less than $20 \%$ (i.e. a prevalence of homozygous recessive allele carriers less than $4 \%$ ), only the dominant model was used. To test whether any association of gene variants with breast cancer risk could be mediated by alterations in circulating levels of IGF-I and/or IGFBP-3, these associations were also estimated with adjustment for serum peptide levels.

Relationships of polymorphic gene variants with serum levels of IGF-I and IGFBP-3 were estimated by standard normal regression models, stratified by EPIC recruitment centre and further adjusted for age. Relationships of polymorphic variants with breast cancer risk (odds ratios) were estimated using conditional logistic regression models, applied on the matched case-control sets. Both series of analyses were performed at the level of single SNP loci, as well as at the level of haplotypes (using the haplotype dosage values). Haplotype analyses were performed at the level of full gene loci - that is, including haplotypes based on all of the SNPs in that gene - and for the IGF1 and IGFBP3 genes also at the level of well-delineated haplotype blocks within a gene. In all haplotype analyses, the most common haplotype was used as the reference category.

Adjustment for potentially relevant variables (body mass index, adult height, total caloric intake) did not alter significantly the results (data not shown). Exclusion of cases diagnosed within a year of blood collection also did not have an impact on the results (data not shown).

Reconstruction of haplotype blocks within each gene was performed with Haploview (http://www.broad.mit.edu/personal/ jcbarret/haploview; Barrett et al, 2005). Block boundaries were determined using the criterion of Gabriel et al (2002).

Subgroup analyses on women with a breast cancer diagnosis either before ( $45 \%$ of the subjects) or after age at diagnosis of 55 years (the age at which over $99 \%$ of women enrolled in the EPIC cohort declared themselves menopausal) were used to examine whether associations of gene variants with breast cancer risk differed between women with cancer at approximately 
premenopausal or postmenopausal age, and possible heterogeneity of effect between these two age groups was tested using a $\chi^{2}$ test.

We estimated the false positive reporting probability (FPRP) for statistically significant observations based on the methods described by Wacholder et al (2004). Prior probability is likely to be influenced by the biological knowledge of the gene, the functional significance of the variants and the available epidemiological evidence. It remains a subjective measure that may vary from one investigator to another based on the importance they assign to the different pieces of evidence. For this reason, we have calculated FPRP for a range of prior probabilities from 50 to $0.1 \%$. We considered that a prior probability of $50 \%$ might be acceptable when there was a very strong biological plausibility with consistent epidemiological evidence (i.e. the association between SNPs in the $5^{\prime}$ part of IGFBP3 and IGFBP-3 level), and a prior probability of $0.1 \%$ may be appropriate when the biological knowledge and epidemiological data were both inadequate (i.e. the majority of other SNPs, whose exact function is not known, and epidemiological data do not exist).

\section{RESULTS}

A total of 807 incident cases of breast cancer from the EPIC cohort and 1588 matched controls were included in our study. The mean age of study subjects at blood donation was 55 years $(5$ th -95 th percentile: 39.9-68.7 years). For cases, the mean age at diagnosis was 57 years (5th-95th percentile: $42-71$ years). Based on the questionnaire data, $32 \%$ of the subjects were premenopausal at blood donation, $10 \%$ were perimenopausal or of unknown menopausal status and 58\% were postmenopausal. Cases had a significantly lower number of full-term pregnancies than controls (means: 2.35 vs 2.47, $P=0.02$ ) and were significantly older at first full-term pregnancy ( $26 v s 25.5$ years in controls, $P=0.02$ ). Age at menarche did not differ between cases and controls, nor did body mass index. Serum levels of IGF-I adjusted for age and centre were not significantly different between cases and controls (means: 248.7 vs $244.4 \mathrm{ng} \mathrm{ml}^{-1}, P=0.15$ ), nor for the subgroups subjects with cancer diagnosis before or at the age of 55 years $(272.0 \mathrm{vs}$ 270.7; $P=0.79)$, or after (224.0 vs $217.5 ; P=0.08)$. Case subjects did show higher mean levels of serum IGFBP-3 than controls (means: 3422 vs $3361 \mathrm{ng} \mathrm{ml}^{-1}, P=0.04$ ). The latter difference, however, was due mostly to the subgroup with cancer diagnosis after age 55 years (3473 vs 3378; $P=0.02)$, and was not clearly visible among the younger women $(3190 v s 3173 ; P=0.66)$. Details on the relationships of IGF-I and IGFBP-3 with breast cancer risk, with an extended series of 1195 beast cancer cases and 2321 control subjects, will be reported elsewhere (Rinaldi et al, manuscript submitted).

The number of SNPs typed per gene ranged from three for IGFALS to eight for IGFBP3. Results of associations between individual SNPs and cancer risk and circulating IGF-I and IGFBP-3 levels are reported in Table 2. Supplementary Tables $2 \mathrm{a}-\mathrm{f}$ report results of analyses relating hormone levels and breast cancer risk to haplotypes.

In the IGF1 gene, we noted an association of the rs2162679 SNP, with the $\mathrm{G} / \mathrm{G}$ genotype being associated with a reduction in risk of breast cancer $(P=0.05)$ and also a modest effect in the heterozygote $(P$-trend for codominant model $=0.03)$. Interestingly, when the cases were stratified by age of onset (less than 55 years old or greater than or equal to 55 years old), this reduction appears to be confined to breast cancer cases with an early age of diagnosis, at 55 years or before, and was strongest (odds ratio 0.17, confidence interval $0.07-0.56$ ) in the homozygous G/G $(P=0.005)$. This association was also found to be statistically significant under the dominant $(P=0.01)$ and codominant $(P=0.002)$ models. Linkage disequilibrium (LD) reconstruction of this region shows that there is strong LD between the rs 2162679 and the two surrounding SNPs, rs35765 and rs35767. As expected, rs35767 and rs35765 also showed a reduction in breast cancer risk among the entire set, although the only statistically significant result was seen for $\mathrm{rs} 35767$ when testing for trend $(P=0.04)$. However, as with rs2162679, the reduction effect was statistically significant in both rs35767 and rs35765 for the breast cancer cases diagnosed at age 55 years or before. Haplotype analysis of the IGF1 data showed only an association between one rare haplotype and cancer risk (Supplementary Table 2). When we analysed the block structure of $I G F 1$, based on our control genotypes, we noted a clear haplotype block that contains rs35765, rs35767 and rs2162679 (Figure 1A). When we restricted our haplotype analysis to only this block, we observed an association between cancer risk and haplotype hCTG, which has a frequency of $4 \%$ and includes the rare alleles of rs35767 and rs2162679. This association was not stronger than that seen with the individual SNPs (Supplementary Table 2).

We also noted a significant decrease in circulating IGFBP-3 levels with the rare homozygous states for both rs2162679 and rs35767 (again representing the LD between these markers). In contrast to the association of breast cancer risk, with the same markers, this effect appeared restricted to a later age of onset in our age-stratified analysis. When we performed the same analysis by using the haplotype block that spans the $5^{\prime}$ end of the gene and includes rs2162679 and rs35767, the same haplotype that is associated with reduced cancer risk appeared also to be strongly associated with decreased IGFBP-3 levels $(P<0.0001)$. The only other result of interest in the IGF1 gene was a relatively modest dominant effect of polymorphisms rs35765, rs35767 and rs6220, resulting in a higher mean circulating IGF-I level, and visible also in the haplotype analysis.

For the IGFBP3 gene, we observed that a number of previous studies showed an increase in circulating IGFBP-3 levels associated with the A allele of a polymorphism in the promoter of IGFBP3 at position -202 (rs2854744) $(P \leqslant 0.0001)$. Reflecting the strong amount of LD in this area (Figure 1B), we also noted a strong association between increased IGFBP-3 levels and alleles of the surrounding polymorphisms, rs2132571, rs2132572, rs2471551, which belong to the same haplotype block (Supplementary Table 2).

The polymorphism P0453 of IGFBP3 also showed a slight increase in the mean circulating IGF-I protein levels and one $I G F B P 3$ haplotype showed an increase in risk of breast cancer, under a recessive model.

Polymorphic variations in the IGFBP1 gene did not show associations with any of the end points. Homozygous carriers of the polymorphism rs3751893 in IGFALS, however, showed a significant reduction in mean circulating IGF-I levels.

\section{DISCUSSION}

We have performed a large-scale association study, nested in the EPIC cohort, to assess the role of genetic variation of IGF1 and of the genes encoding the major IGF-I binding proteins on risk of breast cancer and on circulating levels of IGF-I and IGFBP-3. We genotyped 23 SNPs in the four candidate genes. Our criteria for selecting the SNPs to study were proven existence in the Caucasian population, high allele frequency and/or high chance of having an impact on gene expression or function of the gene product. Our selection of SNPs to be typed was not based on a formal haplotype tagging approach, because we estimated that the available information (as of the time of writing this report) was insufficient to do so accurately. In view of the relative paucity of publicly available (e.g. HapMap) data, an accurate haplotype tagging approach would have required complete resequencing of the gene region in a sufficient number of subjects, in order to establish a complete catalogue of polymorphisms and to examine LD patterns between them. Such effort was beyond the scope 
Table 2 Associations between SNPs and breast cancer risk and mean IGF-I and IGFBP-3 levels adjusted for age and centre

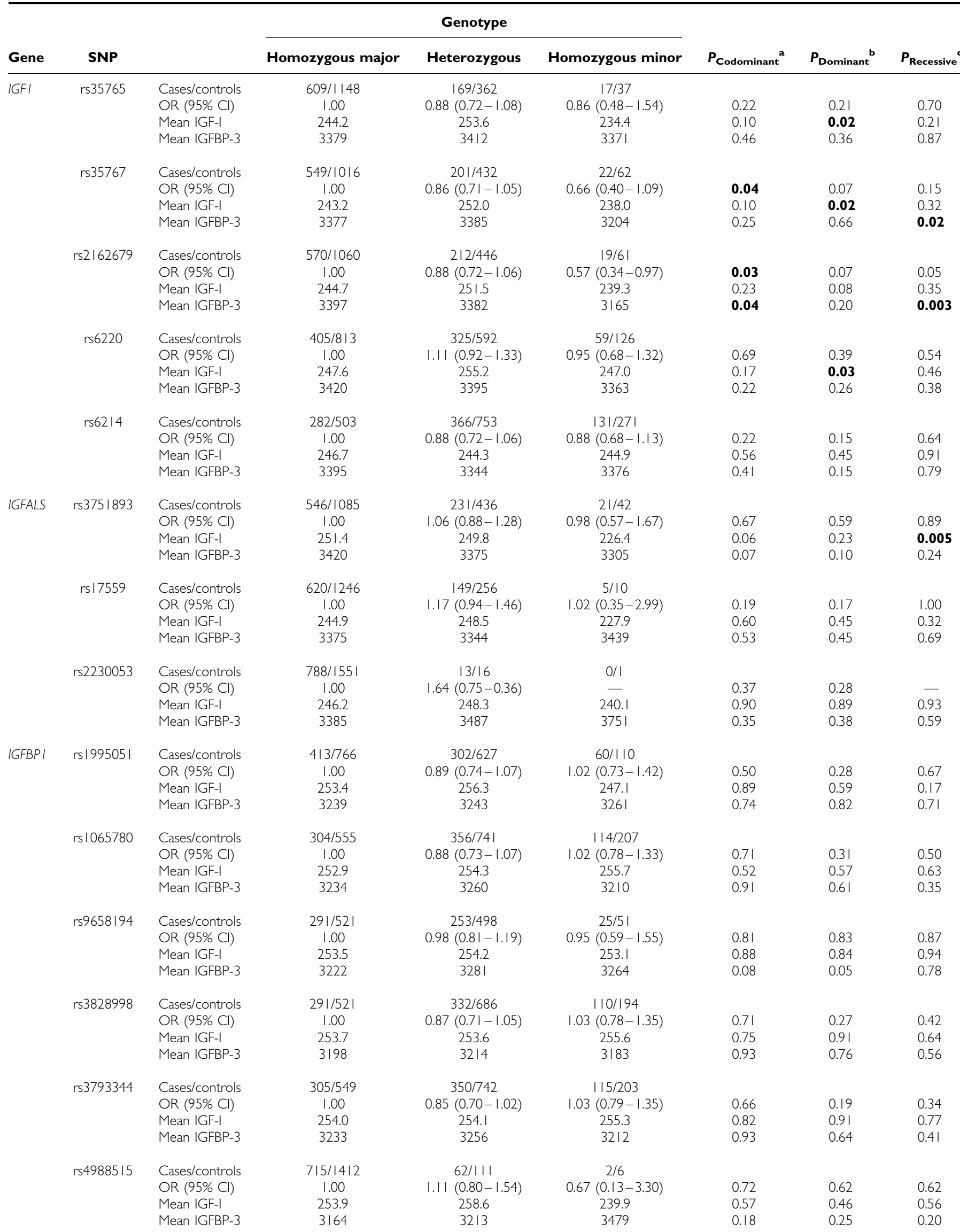


Table 2 (Continued)

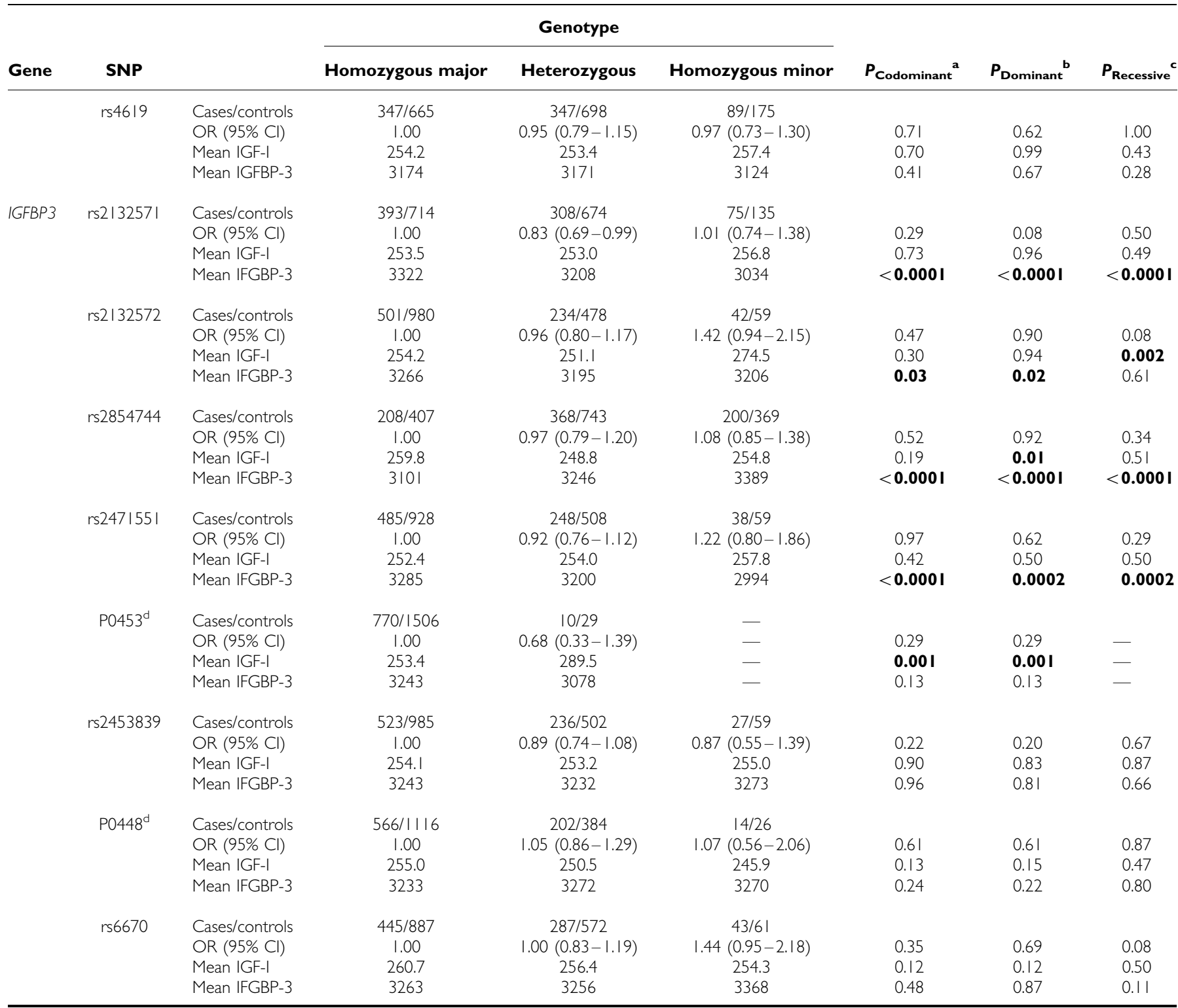

${ }^{a} P$-value for codominant model (trend). ${ }^{b} P$-value for dominant model. ${ }^{c} P$-value for recessive model. SNP = single nucleotide polymorphism; IGF-I = insulin-like growth factor I: IGFBP-3 = insulin-like binding protein-3; OR = odds ratio; $\mathrm{Cl}=$ confidence interval. Mean IGF-I and mean IFGBP-3 are means of hormone levels, expressed in ng/ml, for subjects (cases+controls) belonging to each genotype category, adjusted for age and centre. Internal references are used for polymorphisms not present in dbSNP. P-values that reached statistical significance at the 0.05 level are reported in bold.

of the present project. Nevertheless, we feel that it is unlikely that many new common polymorphisms, which were the focus of our investigation, would have been discovered by systematic resequencing.

The use of a multicentric study raises the possibility of confounding by population stratification. Although $97 \%$ of EPIC subjects are estimated to be of Caucasian origin, there could still be confounding by population stratification if SNP or haplotype allele frequencies varied between the subject recruitment areas, while at the same time there was also variation in average breast cancer incidence rates. We did not observe wide differences in allele frequencies between different countries in our study (data not shown). In addition, breast cancer cases and control subjects were systematically matched for the study centre where they had been recruited into the EPIC cohorts, and we adjusted all statistical analyses of association between SNPs, hormone levels and breast cancer risk for the factor 'recruitment centre'. We believe therefore that confounding by population stratification is not an issue in our study.

We have found an association with decreased breast cancer risk of a haplotype located in the $5^{\prime}$ part of IGF1. This association was particularly strong among women younger than 55 years.

No other variant among the ones we studied showed any association with cancer risk, except for two haplotypes of IGFBP3. These associations are likely to be chance findings, as they are based on small numbers.

Our results suggest that in none of the four genes we examined were there any SNPs that had a strong impact on circulating levels of IGF-I. 


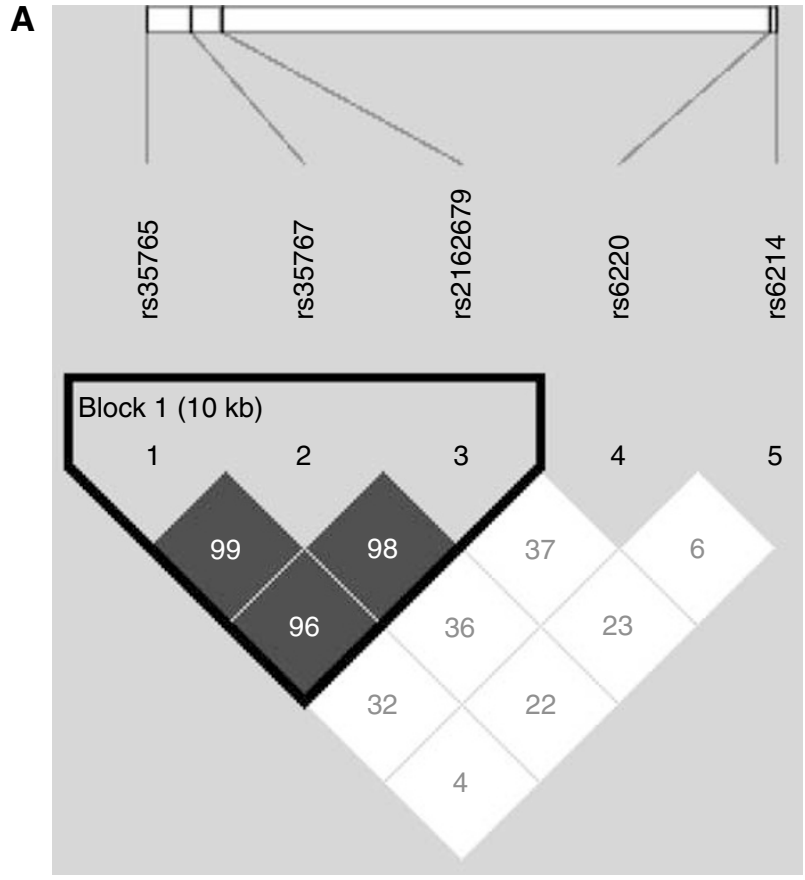

B

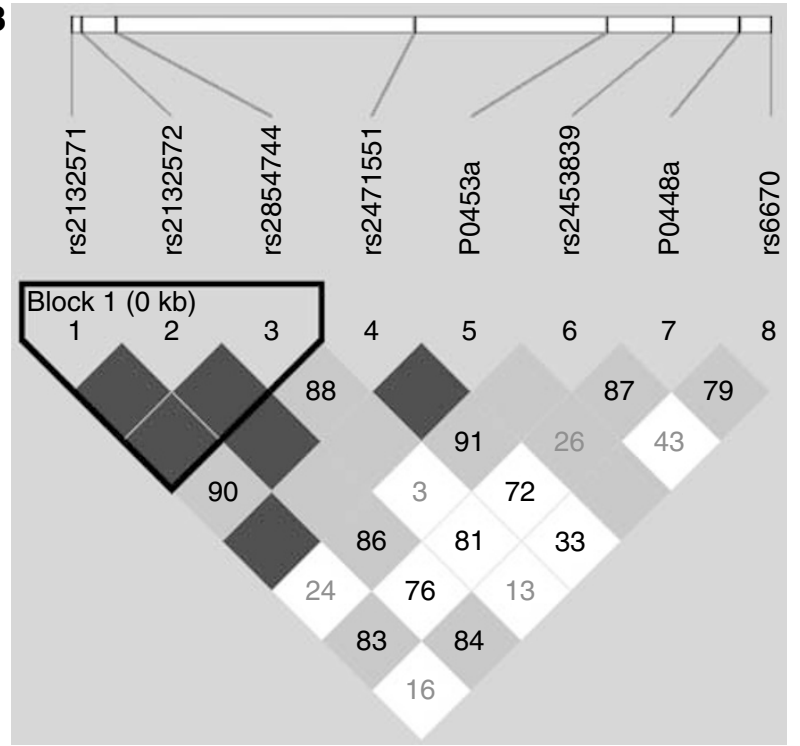

Figure I (A) Graphical representation of LD and block structure of IGFI. (B) Graphical representation of LD and block structure of IGFBP3. The upper bars represent SNPs and physical distances among them. Numbers within squares are pairwise $D^{\prime}$ values. Absence of value means $D^{\prime}=1$. The colour code shows confidence boundaries of LD estimations: black shows evidence of LD, white shows evidence of recombination and grey shows uninformative pairs. Linkage disequilibrium blocks were defined according to the algorithm of Gabriel et al (2002). Internal references are used for polymorphisms not present in dbSNP.

Our results are in conflict with a previous study (Ukkola et al, 2001), which found that carriers of the less frequent $G$ variant allele of SNP rs3793344, located in a region of intron 1 of $I G F B P 1$, which harbours sequences affecting gene expression, had significantly lower circulating levels of IGF-I both before and after overfeeding. Subjects carrying two copies of the A allele had lower IGF-I concentrations before overfeeding, which were further decreased after overfeeding compared to subjects carrying the rarer $\mathrm{G}$ allele. This may indicate that the AA genotype results in higher IGFBP-1 concentrations, which could decrease available IGF-I. We found no evidence of higher IGF-I concentrations with this polymorphism. It is possible that the previously reported association (Ukkola et al, 2001) is linked to the peculiar study conditions (long-term caloric surplus). Alternatively, the association could be due to a statistical fluctuation caused by the small sample size of the study (12 pairs of monozygotic twins).

The finding supported by the strongest statistical evidence in our study is the association of polymorphisms in the $5^{\prime}$ region of IGFBP3 with circulating levels of IGFBP-3. This association has been reported in several previous studies, and has been ascribed to a polymorphism located at position -202 (rs2854744) from the transcription start site (Deal et al, 2001; Jernstrom et al, 2001b; Schernhammer et al, 2003). In accordance with these previous reports, we also found a dose-dependent association of the A allele with increased levels of circulating IGFBP-3. In addition, we observed strong associations of all surrounding polymorphisms with IGFBP-3 levels (Supplementary Table 2). This leads to the question which of these various polymorphisms would be the functional polymorphism causing the association with IGFBP-3 levels. In a recent study in vitro, a construct including only the A allele of the rs2854744 SNP variant was found to increase promoter activity, suggesting that rs2854744 is the functional variant that affects IGFBP-3 transcription, and that the associations we have observed with the other polymorphisms of IGFBP3 are exclusively due to strong LD (Deal et al, 2001).

The -202 polymorphism also has been studied in relation to risk of breast cancer (Deal et al, 2001; Schernhammer et al, 2003) and other cancers (Wang et al, 2003; Li et al, 2004; Slattery et al, 2004). In agreement with most previous studies, we noted no association between this allele in our series as a whole, or in our stratified analysis based on age of onset. Probably, the effect of this polymorphism on circulating IFGBP-3 levels (estimated in 6-9\% of variation) (Jernstrom et al, 2001b; Schernhammer et al, 2003) is not sufficient, by itself, to alter amounts of bioavailable IGF-I sufficiently to lead to a substantial change in cancer risk. In one recent study, however, the $\mathrm{C}$ allele of the -202 polymorphism was found to be associated with more advanced disease status in prostate cancer, even though it was not associated with prostate cancer risk overall (Wang et al, 2003).

Besides polymorphic variation in the IGFBP3 gene, another strong predictor of variability in IGFBP-3 levels was the same IGF1 haplotype that was associated, in the same direction, with cancer risk. This was particularly evident when the analysis was restricted to the haplotypes observed within the strong LD block in the $5^{\prime}$ region of the gene. It is difficult to interpret these associations, with either IGFBP-3 levels or cancer risk, as for none of these SNPs is there any evidence to suggest a possible functional role. Little appears to be known about what genomic elements are involved in the regulation of IGF1 transcription, except for a region immediately upstream of the transcription start (Porcu et al, 1994; Rubini et al, 1994), which however harbours no known genetic variation. We have not typed a CA repeat polymorphism located in the $5^{\prime}$ region of IGF1, between SNPs rs35767 and rs2162679, which has been frequently included in previous studies. Several epidemiological studies on the association between this polymorphism and breast cancer risk or IGF-I levels (Jernstrom et al, 2001a; Yu et al, 2001; Figer et al, 2002; Missmer et al, 2002; DeLellis et al, 2003) have yielded highly conflicting results. This microsatellite polymorphism has a large number of alleles, which results in fractioning the study population into a large number of classes. Even with a large sample size, this makes statistical analysis very difficult. Moreover, there are no studies that show a functional role for this microsatellite. We believe that it is unlikely that the IGF1 CA repeat has a functional role of its own, and that associations previously reported with this microsatellite are likely to reflect LD with the same SNPs that we included in our study or with other, yet unknown SNPs located in the region. In any case, the level of $\mathrm{LD}$ in the $5^{\prime}$ region of the gene is 
so high that an association study approach alone will not be able to single out one particular variant as that causing variation in IGFBP-3 levels and, possibly, cancer risk. Moreover, genetic variation in the promoter of IGF1 should have an impact on circulating IGFBP-3 only through a modification of circulating IGF-I, which we observe only at modest levels. Functional studies will be needed to clarify this point.

Other polymorphic variants that were found to be associated with IGFBP-3 levels - a haplotype in the $5^{\prime}$ region of IGF1, in homozygosity, and SNP rs3751893 of IGFALS - are difficult to evaluate, because of the small number of subjects carrying the alleles that showed the associations.

In summary, the main findings of our study were thus a weak but nominally significant association of a block of polymorphisms located at the $5^{\prime}$ end of the IGF1 gene with breast cancer risk, particularly among women younger than 55 years, and an association of polymorphisms located in the $5^{\prime}$ region of IGFBP3 with circulating levels of IGFBP-3. The large number of statistical tests we have performed raises the issue of potential false positives. An alternative to applying a Bonferroni's correction, which is generally too conservative because of statistical dependence between tests for multiple SNPs that are in LD, is the use of a Bayesian approach, such as the recently introduced calculation of FPRP (Wacholder et al, 2004). Given the absence of previous functional or epidemiologic data on the IGF1 SNPs we found associated with breast cancer risk, we calculated FPRPs by using a prior probability of true association. Calculated FPRPs were high even with a relatively high prior probability of 0.01 that variants would have an association with breast cancer risk or with circulating peptide levels. Our finding relating IGFBP3 SNPs with serum IGFBP-3 levels, however, is strongly backed by previous epidemiologic and functional findings and is also supported by very low $P$-values in our study, and resulted in very low FPRPs over a wide range of prior probabilities of true association.

In conclusion, our results show a number of genetic variants associated with circulating hormone levels, including a convincing

\section{REFERENCES}

Barrett JC, Fry B, Maller J, Daly MJ (2005) Haploview: analysis and visualization of LD and haplotype maps. Bioinformatics 21: 263-265

Bingham S, Riboli E (2004) Diet and cancer - the European Prospective Investigation into Cancer and Nutrition. Nat Rev Cancer 4: 206-215

Bohlke K, Cramer DW, Trichopoulos D, Mantzoros CS (1998) Insulin-like growth factor-I in relation to premenopausal ductal carcinoma in situ of the breast. Epidemiology 9: 570-573

Bruning PF, Van Doorn J, Bonfrer JM, Van Noord PA, Korse CM, Linders TC, Hart AA (1995) Insulin-like growth-factor-binding protein 3 is decreased in early-stage operable pre-menopausal breast cancer. Int $J$ Cancer 62: 266-270

Chan JM, Stampfer MJ, Giovannucci E, Gann PH, Ma J, Wilkinson P, Hennekens CH, Pollak M (1998) Plasma insulin-like growth factor-I and prostate cancer risk: a prospective study. Science 279: 563-566

Deal C, Ma J, Wilkin F, Paquette J, Rozen F, Ge B, Hudson T, Stampfer M, Pollak M (2001) Novel promoter polymorphism in insulin-like growth factor-binding protein-3: correlation with serum levels and interaction with known regulators. J Clin Endocrinol Metab 86: 1274-1280

DeLellis K, Ingles S, Kolonel L, McKean-Cowdin R, Henderson B, Stanczyk F, Probst-Hensch NM (2003) IGF1 genotype, mean plasma level and breast cancer risk in the Hawaii/Los Angeles multiethnic cohort. $\mathrm{Br} J$ Cancer 88: $277-282$

Figer A, Karasik YP, Baruch RG, Chetrit A, Papa MZ, Sade RB, Rizel S, Friedman E, Riezel S (2002) Insulin-like growth factor I polymorphism and breast cancer risk in Jewish women. Isr Med Assoc J 4: 759-762

Gabriel SB, Schaffner SF, Nguyen H, Moore JM, Roy J, Blumenstiel B, Higgins J, DeFelice M, Lochner A, Faggart M, Liu-Cordero SN, Rotimi C, Adeyemo A, Cooper R, Ward R, Lander ES, Daly MJ, Altshuler D (2002) The structure of haplotype blocks in the human genome. Science 296: $2225-2229$ association of IGFBP3 SNPs with IGFBP-3 levels. On the other hand, we have found only weak or no associations of genetic variants in IGF1, IGFBP1, IGFBP3 and IGFALS with breast cancer risk, and further large studies will be required to confirm our findings.

\section{ACKNOWLEDGEMENTS}

This work was funded by Grants DAMD17-01-1-0275 (US Department of Defense) and 5138 (Association pour la Recherche sur le Cancer). James McKay, Rebecca Cleveland and Stéphanie Monnier were supported by Special Training Awards of the International Agency for Research on Cancer. The EPIC study was funded by 'Europe Against Cancer' Programme of the European Commission (SANCO); Ligue contre le Cancer (France); Société 3M (France); Mutuelle Générale de l'Education Nationale; Institut National de la Santé et de la Recherche Médicale (INSERM); German Cancer Aid; German Cancer Research Center; German Federal Ministry of Education and Research; Danish Cancer Society; Health Research Fund (FIS) of the Spanish Ministry of Health; the participating regional governments and institutions of Spain; ISCIII Network RCESP (C03/09), Spain; Cancer Research UK; Medical Research Council, UK; the Stroke Association, UK; British Heart Foundation; Department of Health, UK; Food Standards Agency, UK; the Wellcome Trust, UK; Greek Ministry of Health; Greek Ministry of Education; Italian Association for Research on Cancer; Italian National Research Council; Dutch Ministry of Public Health, Welfare and Sports; Dutch Ministry of Health; Dutch Prevention Funds; LK Research Funds; Dutch ZON (Zorg Onderzoek Nederland); World Cancer Research Fund (WCRF); Swedish Cancer Society; Swedish Scientific Council; Regional Government of Skane, Sweden; Norwegian Cancer Society.

Supplementary Information accompanies the paper on British Journal of Cancer website (http://www.nature.com/bjc)

Giovannucci E, Pollak MN, Platz EA, Willett WC, Stampfer MJ, Majeed N, Colditz GA, Speizer FE, Hankinson SE (2000) A prospective study of plasma insulin-like growth factor-1 and binding protein-3 and risk of colorectal neoplasia in women. Cancer Epidemiol Biomarkers Prev 9: $345-349$

Gleeson LM, Chakraborty C, McKinnon T, Lala PK (2001) Insulin-like growth factor-binding protein 1 stimulates human trophoblast migration by signaling through alpha 5 beta 1 integrin via mitogen-activated protein kinase pathway. J Clin Endocrinol Metab 86: 2484-2493

Hall K, Hilding A, Thoren M (1999) Determinants of circulating insulin-like growth factor-I. J Endocrinol Invest 22: 48-57

Hankinson SE, Willett WC, Colditz GA, Hunter DJ, Michaud DS, Deroo B, Rosner B, Speizer FE, Pollak M (1998) Circulating concentrations of insulinlike growth factor-I and risk of breast cancer. Lancet 351: 1393-1396

Harrela M, Koistinen H, Kaprio J, Lehtovirta M, Tuomilehto J, Eriksson J, Toivanen L, Koskenvuo M, Leinonen P, Koistinen R, Seppala M (1996) Genetic and environmental components of interindividual variation in circulating levels of IGF-I, IGF-II, IGFBP-1, and IGFBP-3. J Clin Invest 98: $2612-2615$

Hasegawa Y, Fujii K, Yamada M, Igarashi Y, Tachibana K, Tanaka T, Onigata K, Nishi Y, Kato S, Hasegawa T (2000) Identification of nove human GH-1 gene polymorphisms that are associated with growth hormone secretion and height. J Clin Endocrinol Metab 85: 1290-1295

Hong Y, Brismar K, Hall K, Pedersen NL, de Faire U (1997) Associations between insulin-like growth factor-I (IGF-I), IGF-binding protein-1, insulin and other metabolic measures after controlling for genetic influences: results from middle-aged and elderly monozygotic twins. J Endocrinol 153: $251-257$

Jernstrom H, Chu W, Vesprini D, Tao Y, Majeed N, Deal C, Pollak M, Narod SA (2001a) Genetic factors related to racial variation in plasma levels of 
insulin-like growth factor-1: implications for premenopausal breast cancer risk. Mol Genet Metab 72: 144-154

Jernstrom H, Deal C, Wilkin F, Chu W, Tao Y, Majeed N, Hudson T, Narod SA, Pollak M (2001b) Genetic and nongenetic factors associated with variation of plasma levels of insulin-like growth factor-I and insulin-like growth factor-binding protein-3 in healthy premenopausal women. Cancer Epidemiol Biomarkers Prev 10: 377-384

Jones JI, Gockerman A, Busby Jr WH, Wright G, Clemmons DR (1993) Insulin-like growth factor binding protein 1 stimulates cell migration and binds to the alpha 5 beta 1 integrin by means of its Arg-Gly-Asp sequence. Proc Natl Acad Sci USA 90: 10553-10557

Kaaks R, Berrino F, Key T, Rinaldi S, Dossus L, Biessy C, Secreto G, Amiano $\mathrm{P}$, Bingham S, Boeing H, Bueno de Mesquita HB, Chang-Claude J, ClavelChapelon F, Fournier A, van Gils CH, Gonzalez CA, Gurrea AB, Critselis E, Khaw KT, Krogh V, Lahmann PH, Nagel G, Olsen A, Onland-Moret NC, Overvad K, Palli D, Panico S, Peeters P, Quiros JR, Roddam A, Thiebaut A, Tjonneland A, Chirlaque MD, Trichopoulou A, Trichopoulos D, Turnino R, Vineis P, Norat T, Ferrari P, Slimani N, Riboli E (2005a) Serum sex steroids in premenopausal women and breast cancer risk within the European Prospective Investigation into Cancer and Nutrition (EPIC). J Natl Cancer Inst 97: 755-765

Kaaks R, Lukanova A (2001) Energy balance and cancer: the role of insulin and insulin-like growth factor-I. Proc Nutr Soc 60: 91-106

Kaaks R, Rinaldi S, Key TJ, Berrino F, Peeters PH, Biessy C, Dossus L, Lukanova A, Bingham S, Khaw KT, Allen NE, Bueno-de-Mesquita HB, van Gils CH, Grobbee D, Boeing H, Lahmann PH, Nagel G, Chang-Claude J, Clavel-Chapelon F, Fournier A, Thiebaut A, Gonzalez CA, Quiros JR, Tormo MJ, Ardanaz E, Amiano P, Krogh V, Palli D, Panico S, Tumino R, Vineis P, Trichopoulou A, Kalapothaki V, Trichopoulos D, Ferrari P, Norat T, Saracci R, Riboli E (2005b) Postmenopausal serum androgens, oestrogens and breast cancer risk: the European prospective investigation into cancer and nutrition. Endocr Relat Cancer 12: 1071-1082

Kaaks R, Toniolo P, Akhmedkhanov A, Lukanova A, Biessy C, Dechaud H, Rinaldi S, Zeleniuch-Jacquotte A, Shore RE, Riboli E (2000) Serum Cpeptide, insulin-like growth factor (IGF)-I, IGF-binding proteins, and colorectal cancer risk in women. J Natl Cancer Inst 92: 1592-1600

Li L, Cicek MS, Casey G, Witte JS (2004) No association between genetic polymorphisms in IGF-I and IGFBP-3 and prostate cancer. Cancer Epidemiol Biomarkers Prev 13: 497-498

Lopez-Bermejo A, Buckway CK, Rosenfeld RG (2000) Genetic defects of the growth hormone-insulin-like growth factor axis. Trends Endocrinol Metab 11: 39-49

Ma J, Pollak MN, Giovannucci E, Chan JM, Tao Y, Hennekens CH, Stampfer MJ (1999) Prospective study of colorectal cancer risk in men and plasma levels of insulin-like growth factor (IGF)-I and IGF-binding protein-3. J Natl Cancer Inst 91: 620-625

Mantzoros CS, Tzonou A, Signorello LB, Stampfer M, Trichopoulos D, Adami HO (1997) Insulin-like growth factor 1 in relation to prostate cancer and benign prostatic hyperplasia. Br J Cancer 76: 1115-1118

Missmer SA, Haiman CA, Hunter DJ, Willett WC, Colditz GA, Speizer FE, Pollak MN, Hankinson SE (2002) A sequence repeat in the insulin-like growth factor-1 gene and risk of breast cancer. Int J Cancer 100: $332-336$

Mohan S, Baylink DJ (2002) IGF-binding proteins are multifunctional and act via IGF-dependent and -independent mechanisms. J Endocrinol 175: $19-31$

Muti P, Quattrin T, Grant BJ, Krogh V, Micheli A, Schunemann HJ, Ram M, Freudenheim JL, Sieri S, Trevisan M, Berrino F (2002) Fasting glucose is a risk factor for breast cancer: a prospective study. Cancer Epidemiol Biomarkers Prev 11: $1361-1368$

Palmqvist R, Hallmans G, Rinaldi S, Biessy C, Stenling R, Riboli E, Kaaks R (2002) Plasma insulin-like growth factor 1 , insulin-like growth factor binding protein 3, and risk of colorectal cancer: a prospective study in northern Sweden. Gut 50: $642-646$

Perks CM, Newcomb PV, Norman MR, Holly JM (1999) Effect of insulin-like growth factor binding protein-1 on integrin signalling and the induction of apoptosis in human breast cancer cells. J Mol Endocrinol 22: 141-150

Peyrat JP, Bonneterre J, Hecquet B, Vennin P, Louchez MM, Fournier C, Lefebvre J, Demaille A (1993) Plasma insulin-like growth factor-1 (IGF-1) concentrations in human breast cancer. Eur J Cancer 29A: 492-497

Porcu P, Grana X, Li S, Swantek J, De Luca A, Giordano A, Baserga R (1994) An E2F binding sequence negatively regulates the response of the insulin-like growth factor 1 (IGF-I) promoter to simian virus $40 \mathrm{~T}$ antigen and to serum. Oncogene 9: 2125-2134
Rajaram S, Baylink DJ, Mohan S (1997) Insulin-like growth factor-binding proteins in serum and other biological fluids: regulation and functions. Endocr Rev 18: 801 - 831

Riboli E, Hunt KJ, Slimani N, Ferrari P, Norat T, Fahey M, Charrondiere UR, Hemon B, Casagrande C, Vignat J, Overvad K, Tjonneland A, ClavelChapelon F, Thiebaut A, Wahrendorf J, Boeing H, Trichopoulos D, Trichopoulou A, Vineis P, Palli D, Bueno-De-Mesquita HB, Peeters PH, Lund E, Engeset D, Gonzalez CA, Barricarte A, Berglund G, Hallmans G, Day NE, Key TJ, Kaaks R, Saracci R (2002) European Prospective Investigation into Cancer and Nutrition (EPIC): study populations and data collection. Public Health Nutr 5: 1113-1124

Rubini M, Werner H, Gandini E, Roberts Jr CT, LeRoith D, Baserga R (1994) Platelet-derived growth factor increases the activity of the promoter of the insulin-like growth factor-1 (IGF-1) receptor gene. Exp Cell Res 211: 374-379

Schernhammer ES, Hankinson SE, Hunter DJ, Blouin MJ, Pollak MN (2003) Polymorphic variation at the -202 locus in IGFBP3: influence on serum levels of insulin-like growth factors, interaction with plasma retinol and vitamin D and breast cancer risk. Int J Cancer 107: 60-64

Slattery ML, Samowitz W, Curtin K, Ma KN, Hoffman M, Caan B, Neuhausen S (2004) Associations among IRS1, IRS2, IGF1, and IGFBP3 genetic polymorphisms and colorectal cancer. Cancer Epidemiol Biomarkers Prev 13: $1206-1214$

Stattin P, Bylund A, Rinaldi S, Biessy C, Dechaud H, Stenman UH, Egevad L, Riboli E, Hallmans G, Kaaks R (2000) Plasma insulin-like growth factor-I, insulin-like growth factor-binding proteins, and prostate cancer risk: a prospective study. J Natl Cancer Inst 92: 1910-1917

Stram DO, Haiman CA, Hirschhorn JN, Altshuler D, Kolonel LN, Henderson BE, Pike MC (2003a) Choosing haplotype-tagging SNPS based on unphased genotype data using a preliminary sample of unrelated subjects with an example from the Multiethnic Cohort Study. Hum Hered 55: $27-36$

Stram DO, Leigh PC, Bretsky P, Freedman M, Hirschhorn JN, Altshuler D, Kolonel LN, Henderson BE, Thomas DC (2003b) Modeling and E-M estimation of haplotype-specific relative risks from genotype data for a case-control study of unrelated individuals. Hum Hered 55: 179-190

Thissen JP, Ketelslegers JM, Underwood LE (1994) Nutritional regulation of the insulin-like growth factors. Endocr Rev 15: 80 - 101

Toniolo P, Bruning PF, Akhmedkhanov A, Bonfrer JM, Koenig KL, Lukanova A, Shore RE, Zeleniuch-Jacquotte A (2000) Serum insulin-like growth factor-I and breast cancer. Int J Cancer 88: 828-832

Ukkola O, Sun G, Bouchard C (2001) Insulin-like growth factor 2 (IGF2) and IGF-binding protein 1 (IGFBP1) gene variants are associated with overfeeding-induced metabolic changes. Diabetologia 44: 2231-2236

Vaessen N, Heutink P, Janssen JA, Witteman JC, Testers L, Hofman A, Lamberts SW, Oostra BA, Pols HA, van Duijn CM (2001) A polymorphism in the gene for IGF-I: functional properties and risk for type 2 diabetes and myocardial infarction. Diabetes 50: 637-642

Verhaeghe J, Loos R, Vlietinck R, Herck EV, van Bree R, Schutter AM (1996) C-peptide, insulin-like growth factors I and II, and insulin-like growth factor binding protein-1 in cord serum of twins: genetic versus environmental regulation. Am J Obstet Gynecol 175: 1180-1188

Wacholder S, Chanock S, Garcia-Closas M, El Ghormli L, Rothman N (2004) Assessing the probability that a positive report is false: an approach for molecular epidemiology studies. J Natl Cancer Inst 96: $434-442$

Wang L, Habuchi T, Tsuchiya N, Mitsumori K, Ohyama C, Sato K, Kinoshita H, Kamoto T, Nakamura A, Ogawa O, Kato T (2003) Insulinlike growth factor-binding protein-3 gene $-202 \mathrm{~A} / \mathrm{C}$ polymorphism is correlated with advanced disease status in prostate cancer. Cancer Res 63: 4407-4411

Wolk A, Mantzoros CS, Andersson SO, Bergstrom R, Signorello LB, Lagiou P, Adami HO, Trichopoulos D (1998) Insulin-like growth factor 1 and prostate cancer risk: a population-based, case-control study. $J$ Natl Cancer Inst 90: $911-915$

Xiao W, Oefner PJ (2001) Denaturing high-performance liquid chromatography: a review. Hum Mutat 17: 439-474

Yu H, Jin F, Shu XO, Li BD, Dai Q, Cheng JR, Berkel HJ, Zheng W (2002) Insulin-like growth factors and breast cancer risk in Chinese women. Cancer Epidemiol Biomarkers Prev 11: 705-712

Yu H, Li BD, Smith M, Shi R, Berkel HJ, Kato I (2001) Polymorphic CA repeats in the IGF-I gene and breast cancer. Breast Cancer Res Treat 70: $117-122$ 